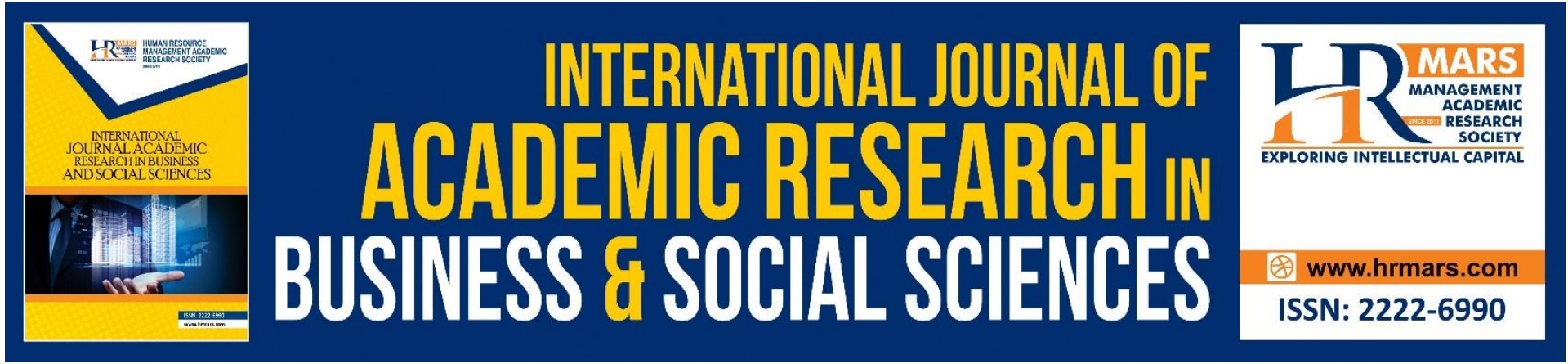

\title{
Social Media During the Movement Control Order (MCO) Period in Malaysia: Uses and Effects
}

Nur Syuhaidah Ayub, Mohd Syuhaidi Abu Bakar

To Link this Article: http://dx.doi.org/10.6007/IJARBSS/v11-i9/10974

DOI:10.6007/IJARBSS/v11-i9/10974

Received: 04 July 2021, Revised: 27 July 2021, Accepted: 20 August 2021

Published Online: 07 September 2021

In-Text Citation: (Ayub \& Bakar, 2021)

To Cite this Article: Ayub, N. S., \& Bakar, M. S. A. (2021). Social Media During the Movement Control Order (MCO) Period in Malaysia: Uses and Effects. International Journal of Academic Research in Business and Social Sciences, 11(9), 49-56.

Copyright: (c) 2021 The Author(s)

Published by Human Resource Management Academic Research Society (www.hrmars.com)

This article is published under the Creative Commons Attribution (CC BY 4.0) license. Anyone may reproduce, distribute, translate and create derivative works of this article (for both commercial and non-commercial purposes), subject to full attribution to the original publication and authors. The full terms of this license may be seen at: http://creativecommons.org/licences/by/4.0/legalcode

Vol. 11, No. 9, 2021, Pg. 49 - 56

http://hrmars.com/index.php/pages/detail/IJARBSS

JOURNAL HOMEPAGE

Full Terms \& Conditions of access and use can be found at http://hrmars.com/index.php/pages/detail/publication-ethics 


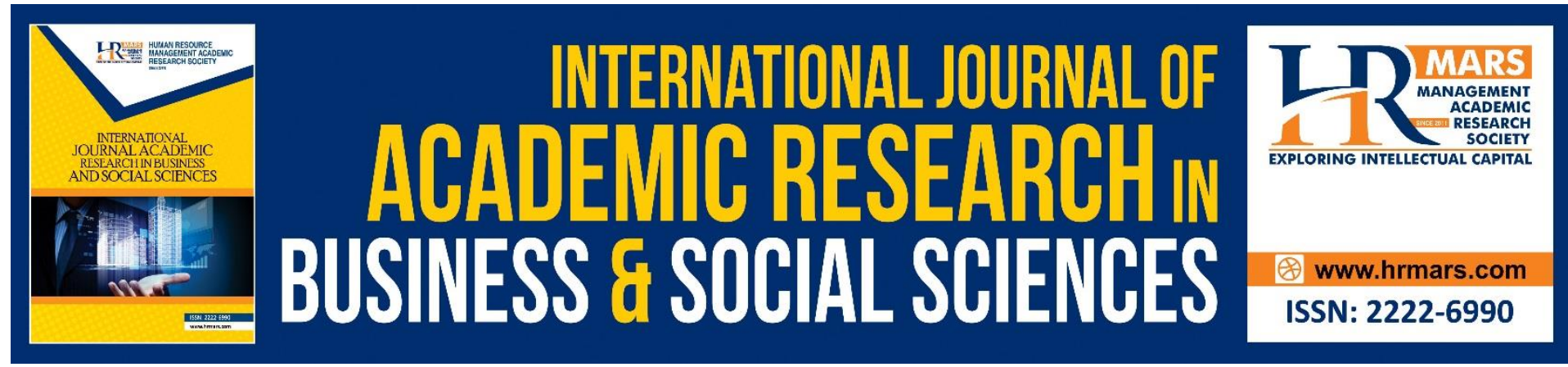

\title{
Social Media During the Movement Control Order (MCO) Period in Malaysia: Uses and Effects
}

\author{
Nur Syuhaidah Ayub
}

Faculty of Film, Theatre and Animation, Universiti Teknologi MARA (UiTM), Malaysia

Email: nursyuhaidahbintiayub@gmail.com,2019973023@isiswa.uitm.edu.my

Mohd Syuhaidi Abu Bakar

Faculty of Film, Theatre and Animation, Universiti Teknologi MARA (UiTM), Malaysia Email: syuhaidi@uitm.edu.my

\begin{abstract}
The COVID-19 pandemic has led many countries to implement the Movement Control Order (MCO) that leads to the temporary closure of schools, workplaces, and entertainment centres. Fellow citizens have used available applications throughout the period and subsequently raised the question about the use and effects of active social media usage among Malaysians. Therefore, this article conducted several interviews to explore the trend of social media use during the MCO period in Malaysia and its effect. The findings show that the use of social media during the MCO period is divided into five purposes: education, entertainment, income generation, information retrieval, and communication. The effects of the use of social media during the MCO period can be classified into four categories, which are effects towards physical health, emotional \& mental health, usage of time, and ease of life, which are further divided into effects towards education and career.
\end{abstract}

Keywords: Movement Control Order, Uses of Social Media, Effects of Social Media Use, Malaysia, COVID-19

\section{Introduction}

Social media are important for communicating and sharing information. According to Amir (2020), the use of social media or online platforms will remain the norm for Malaysians until the end of the Movement Control Order (MCO). This includes university students who have been actively used online platforms for purposes such as information gathering purposes. There was a significant increase in online usage occurred immediately after the announcement of the MCO on March 18, 2020 in Malaysia. The Turnitin and Grammarly usage also increases due to online classes and academic writing programmes.

Students, among other parties, are significantly affected by the MCO. However, other groups have also been affected by this pandemic. Malaysia Gazette (2020) reports that the psychological level of Malaysians has been affected by the MCO and the COVID-19 pandemic. However, the government has taken a number of initiatives to address such issue including the establishment of the Talian Kasih hotline to provide online psychological support to the 
community. The Talian Kasih hotline offers counselling service that helps those who are affected by the COVID-19 pandemic.

Several studies report that the public whose movements are restricted have resorted to the use of social media use and online applications and has relied on online services. This provides valuable insight on the prominent importance of online applications and services to ease the public's lives during the MCO period.

However, the active use of social media and online platforms among the public has led to several issues. Malik (2020) reported that there was a significant increase in the number of cybercrime cases, with 283 reported cases as compared to the previous year. The most reported cases are fraud or online scammers. Therefore, the public is advised to be alert upon receiving suspicious calls, text messages, or links. Since the emergence of the COVID-19 pandemic, e-commerce have significantly increased as the public has resorted to online purchases due to limited movements. These online sales take place on online platforms like Facebook, Shoppe, and Lazada.

The aim of the study is to explore the use of social media and its effects on Malaysians during the MCO period in Malaysia.

\section{Literature Review}

\section{Social Media as a Communication Tool}

A study by Khatijatusshalihah and Syahira (2018) suggests that the Internet has changed human life. This technology facilitates a variety of activities and has become a necessity for people. The study also found that most young people spend 8 hours per day on the Internet, affecting not only young people but also children.

In addition, Khatijatusshalihah and Syahira (2018) also investigated on the purpose of Internet use, Internet accessibility, the pattern of Internet use, and the impact of Internet on youth development. They have also explored the educational characteristics acquired by young people from their use of the Internet. The results show that the impact of Internet use is divided in positive and negative according to the purpose of its use. This highlights the need for parents to take precautionary measures that can reduce negative effects, especially on children.

Moreover, the use of the Internet is considered inevitable, in particular because of its implementation in the field of education. One of the popular uses of the Internet is to access the social media. In relation to Khatijatusshalihah and Syahira (2018), this study aims to discuss the inevitability of the use of the Internet and social media during the MCO period, particularly when these facilities are utilized by most educational institutions in order to communicate and share information.

Social media has become a significant option between community, especially with the arrival of the Internet. Destiana, Salman and Abd Rahim (2013) examines the acceptance and use of social media among 298 university students in Indonesia using the Technology Acceptance Model by Davis (1989). The result is aligned with the Technology Acceptance Model (TAM) by Davis (1989).

This indicates the important use of the Internet and social media, particularly in the area of communication and education. Social media serves as a platform for mediating communication between youth and the surrounding community. It is also a medium to search for useful data or information related both to the academic world and for entertainment. 


\section{The Use and Effects of Social Media Among Youths}

Abdullah, Hassan, Sallehhudin, and Omar (2016) investigated the usage trend and outcome of social media usage among 185 students who enrolled into foundation programmes at Kolej Universiti Islam Antarabangsa Selangor (KUIS), Malaysia. The findings suggest that the students subscribe to a minimum of one social media platform with a significant positive relationship between their use of social media with educational purposes as reflected in their academic performance.

Meanwhile, Destiana and Salman (2015) also conducted research on the acceptance, usage, and impact of the use of social media among university students. The study adapts the Technology Acceptance Model (TAM) by Davis (1989) by adding the social influence factor in addition to the existing main factors of ease of use and functionality. The results reveal that social media is encouraging users from the global community to use, contribute and share. Social media also has a positive influence on social policy, such as sharing reviews, issues, problems, and solutions.

The problem of using social media among young people was also studied by Rantai, Hamdan and Abdul Hamid (2014) with a particular focus on the purpose and frequency of the use of social media as well as the use of social media to create positive effects. The study reports that Facebook, Twitter, and YouTube are the three main social media commonly subscribed by students with the aim of communicating, entertaining and getting the latest news. Students also agree that social media positively helps their academic performance.

Such findings justifies the importance of social media among youths. As advocated in previous studies, there is a significant positive relationship between social media and its users, particularly in the aspect of communication, education, and developing social relationship.

However, Abdalqader et al (2018) report on the negative health impact of Internet use. The study revealed that the existence of the Internet, social media and gadgets leads to the appearance of insomnia particularly after their high frequency of access to social networks, access to social networks during night and evening, and its tendency to use gadgets in bed before going to sleep. This suggests the relationship between social media and various socio-demographic factors with respect to the issue of insomnia among university students. Such finding hence justifies the need to study the effects of the use of social media among Malaysians, particularly during the MCO period.

A study by Ismail, Ahmad, Noor and Saw (2019) examines the use of social media among youths in the context of natural disasters. It is found that young people portray greater confidence in the news about natural disasters that social media have produced because of its speed, confidence and accuracy. News about the natural disasters they commonly accept include floods, landslides and mist. Therefore, the authorities should play an important role in the dissemination of current news and issues on social media, in particular in relation to important issues such as natural disasters.

Nevertheless, the use of social media to broadcast news is subject to the likelihood that false news will be spread. Such issue is also prominent in the context of the MCO where the spread of fake news via social media is obvious particularly when the public is overwhelmed with panic and in dealing with the COVID-19 pandemic.

\section{Methodology}

This study uses a qualitative interview method as the method of data collection. According to Hennink, Kaiser, and Marconi (2016), small quantities of interview of informant are sufficient to grasp the saturation point of data. A total of ten (10) members of the public participated 
in the interview and the data were transcribed for further analysis. The informants are composed of three main categories: students, employees and the unemployed in Malaysia, who offer different perspectives on the use of social media according to their daily needs and needs. The interview data were transcribed verbatim. The results are presented as a findings framework for the benefit of future researches.

\section{Findings and Discussion}

The results indicate that 5 informants are students who stayed at home throughout the MCO period, 3 informants are employed and 2 informants are unemployed.

\section{Social Media Use During the Movement Control Order (MCO) Period in Malaysia}

Based on interviews, all informants use social media and have specific reasons to use social media during the MCO period. Among the social media heavily used by informants during the MCO period include Facebook, Twitter and Instagram. Facebook is used by Informant 1, 2, 3, 4, 6, 7, 8, 9 and 10; Twitter is used by Informant 1, 2, 4, 5, 6, 8 and 10; and Instagram is used by Informant 1, 3, 4, 5, 6, 7, 8 and 9 . Most informants use Facebook, Twitter and Instagram to communicate, as well as to obtain information, latest issues and entertainment of artists and celebrities around the world. In addition to 3 the social media platforms, informants use or subscribe to other social networks such as YouTube, WhatsApp, Netflix, Viu, WeTv and Huawei Video. Most informants agree on the increase in the use of social media during the MCO period, with the exception of Informant 8.

In the context of education, Informant 1 states that she used social media to handle academic assignments and notes from her lecturers via WhatsApp. A similar response is provided by Informant 4 and 9 . There are also informants who utilise social media for entertainment purposes. This includes Informant 3 who used social media to avoid feeling lonely, as well as Informant 5 who made social networks as companion while performing tasks at work.

Informant 7 used social media as a medium to spend time with her children who couldn't go to school during the MCO period. In her response, she admitted that she had watched videos with her children on YouTube. In addition, Informant 6 agreed that there has been an increase in his use of social media. However, such increase is moderate because he rarely uses his smartphone or laptop. From the perspective of earning income, Informant 9 states that he used various social media to promote his products.

$\mathrm{He}$ is a student who uses social media to earn side incomes and the increase in his use of social media during the MCO period is due to promotional activities of his products. In the meantime, Informant 10 is an employee who utilises social media for the purpose of working from home, especially to communicate with her colleagues and family members.

Furthermore, most informants admit that they browsed social networks to obtain information about current issues. Informant 2 states that he used social media to obtain the latest information from reliable and trusted sources like The Ministry of Health (MOH). The information, in this context, refers to the current situation of COVID-19 as well as the MCO status.

Finally, a major portion of the informants' responses on their usage of social media is also inclined towards communication. Although the term "communication" has not been explicitly mentioned by them, all informants of the three categories of students, employees, and unemployed admit that they use social media to contact their families, friends, employers, colleagues, as well as lecturers as a continuum to their norms prior to MCO. This 
indicates that communication, particularly via social media, is important for the informants throughout the MCO period, which involves various communication contexts.

The use of social media has been a norm since before the implementation of the MCO. This increase is motivated by the fact that informants must continue to meet their norms prior to the MCO. Without social media, the reachability of education, entertainment, earning income, information, and communication would be difficult to achieve. The use of social media by the informants can be classified into 5 categories, namely for entertainment, education, income generation, information retrieval, and communication. Figure 1 contains the framework of social media use during the MCO period in Malaysia.

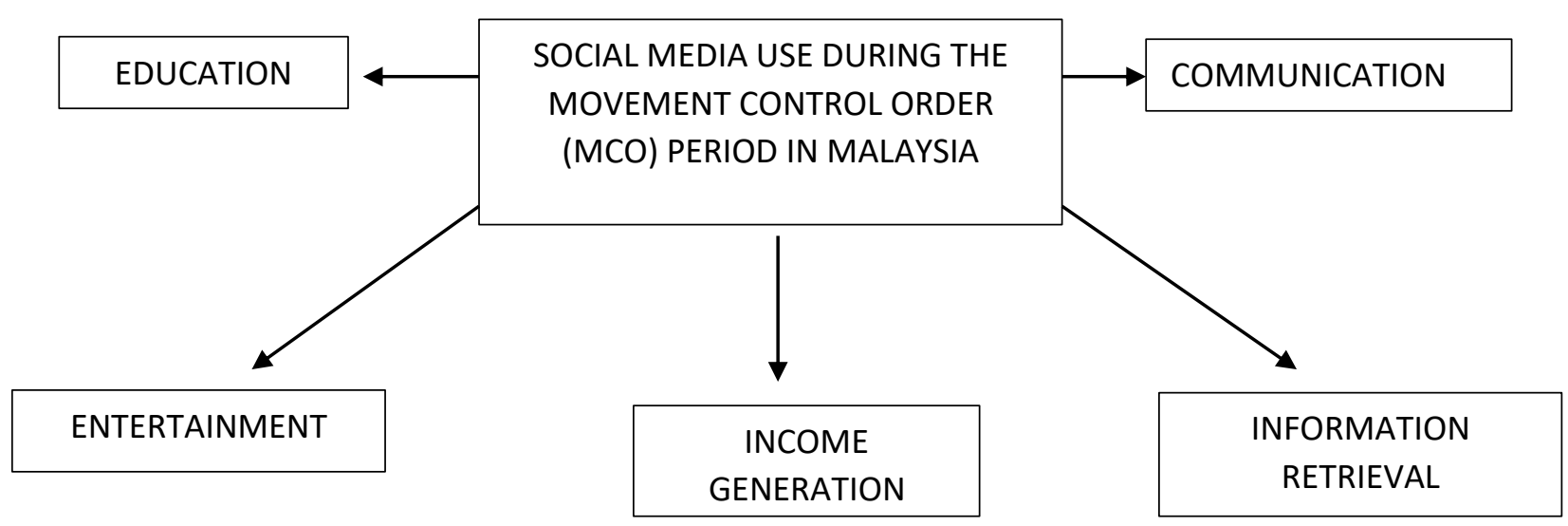

Figure 1: Social Media Use During the Movement Control Order (MCO) Period in Malaysia

\section{The Effects of Social Media Use During the Movement Control Order (MCO) Period in Malaysia}

It is undeniable that the use of social media affects its users during the MCO period. However, three informants have stated otherwise. Informant 4 and 7 state that there is no significant difference in their use of social media before and during the MCO period, while Informant 6 uses only social media to communicate with colleagues, friends and family as usual.

Health is among the effects of the use of social media that is commonly experienced by the informants. Informant 1 stated that information about the negative aspects of COVID19 affected her emotional and mental health. Meanwhile, bodyweight gain is also a major physical health problem experienced by Informant 5 and 10 .

However, there are also a number of positive effects of the use of social media. Informant 2 states that social media reduce the feeling of loneliness and pressure caused by $\mathrm{MCO}$, which positively affects his mental health. A similar response is also recorded by Informant 9 who said that he would feel more pressured and depressed about having to stay at home during the MCO if he do not have access to social media.

Informant 3 admits that social media usage has affected her use of time. This is due to the fact that the extensive use of social media has negatively altered her timing and daily schedule during the MCO period.

However, another positive effect raised by the use of social media during the MCO period is ease of life. Informant 8 admits that social media made her study easier by enabling her to search for information, complete tasks, and communicate with teachers. Informant 10 also provides a similar response in the context of her career. 
These results therefore suggest that the use of social media affects the physical health, emotion and spirit of the informants and facilitates their lives in terms of educational and career tasks. The health effects are more prominent compared to other aspects.

Figure 2 shows the effects of social media use during the MCO period in Malaysia.

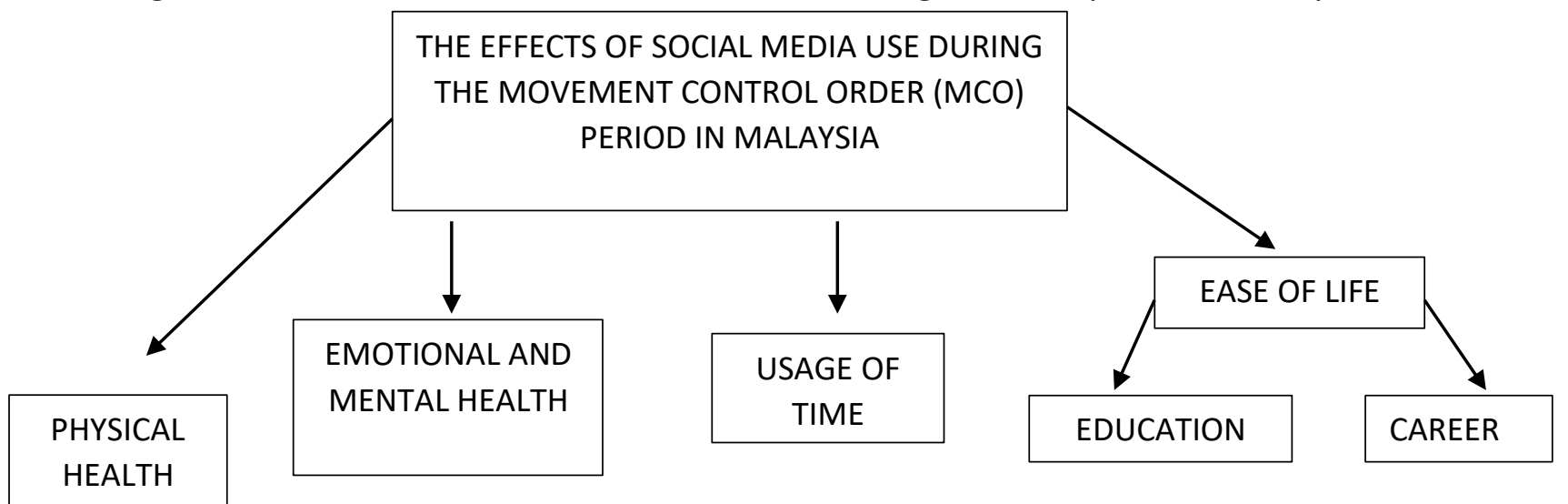

Figure 2: The Effects of Social Media Use During the Movement Control Order (MCO) Period in Malaysia

\section{Conclusion}

In conclusion, the use of social media is now a norm in the present community. The results show that the use of social media is not limited for entertainment purposes, but also in other areas, as shown in Figure 1. The effects of using social media vary, as shown in Figure 2. Informants believe that access to social media as a way of compromising the restriction of movement and the limited social interaction caused by the MCO. Despite the positive and negative effects, informants suggest that the positive implications are greater, suggesting the importance of social media to support the emotional and mental health of the public, particularly to continue their daily life during the MCO period.

\section{Corresponding Author}

Mohd Syuhaidi Abu Bakar

Faculty of Film, Theatre and Animation (FiTA) Universiti Teknologi MARA (UiTM), Shah Alam, Malaysia

Email: syuhaidi@uitm.edu.my

\section{Acknowledgements}

The publication fee for this article is funded by the Faculty of Film, Theatre and Animation, Universiti Teknologi MARA (UiTM), Malaysia.

\section{References}

Abdalqader, M. A., Ariffin, I. A., Ghazi, H. F., Abobakr, M. F., \& Fadzil, M. A. (2018). Prevalence of Insomnia and Its Association with Social Media Usage among University Students in Selangor, Malaysia, 2018. Folia Medica Indonesiana, 54(4), 289. doi: 10.20473/fmi.v54i4.10715

Abdullah, N. H., Hassan, N. A., Sallehhudin, I. S., \& Omar, F. I. (2016). The Wired Generation among University Students in Malaysia. International Journal of Applied Linguistics and 
English Literature, 5(6), 221-227. doi: 10.7575/aiac.ijalel.v.5n.6p.221.

Amir, M. T. (2020). COVID: PENGGUNAAN ATAS TALIAN AKAN MENJADI NORMAL BAHARU MESKIPUN SETELAH PKP DIBUBARKAN - Universiti Malaysia Kelantan. Retrieved from https://www.umk.edu.my/index.php/ms/penerbitan/berita-terkini/4-latest-news/466covid-penggunaan-atas-talian-akan-menjadi-normal-baharu-meskipun-setelah-pkpdibubarkan.

Destiana, I., \& Salman, A. (2015). The acceptance, usage and impact of social media among university students. e-BANGI: Jurnal Sains Sosial Dan Kemanusiaan, 12(4), 58-65. Retrieved from http://journalarticle.ukm.my/9349/1/058-065_Social_Media_ImpactIka.pdf.

Destiana, I., Salman, A., \& Abd Rahim, H. (2013). Penerimaan media sosial: kajian dalam kalangan pelajar universiti di Palembang. Jurnal Komunikasi Malaysian Journal of Communication, 29(2), 125-140. Retrieved from

http://journalarticle.ukm.my/6912/1/V29_2_125-140.pdf.

Hennink, M. M., Kaiser, B. N., \& Marconi, V. C. (2016). Code saturation versus meaning saturation. Qualitative Health Research, 27(4), 591-608.

doi:10.1177/1049732316665344.

Ismail, N., Ahmad, J., Noor, S. M., \& Saw, J. (2019). Malaysian Youth, Social Media Following, and Natural Disasters: What Matters Most to Them? Media Watch, 10(3), 508-521. doi: 10.15655/mw/2019/v10i3/49690.

Khatijatusshalihah and Syahira, R. (2018). The effect of internet on youth: What we know, what we do not know and what we need to know. Paper presented at the International Conference on the Roles of Parents in Shaping Children's Characters (ICECED), Anjong Mon Mata, Banda Aceh, Indonesia.

Malaysia Gazette. (2020). Pasca PKP dan sokongan kesihatan mental berterusan. Retrieved from https://malaysiagazette.com/2020/04/30/pasca-pkp-dan-sokongan-kesihatanmental-berterusan/.

Malik, H. (2020). PKP: Jenayah siber catat peningkatan 283 kes di Selangor. Retrieved from http://www.astroawani.com/berita-malaysia/pkp-jenayah-siber-catat-peningkatan283-kes-di-selangor-238666.

Rantai, A., Hamdan, M. D., \& Abdul Hamid, S. S. (2014). Influence of social media in enhancing positive relationship among youth. Paper presented in the Seminar Kebangsaan Integriti Keluarga 2014 (SKIK 2014). Retrieved from https://www.ums.edu.my/fpp/images/download/proseding_skik2014/Muhammad_da niel_hamdan.pdf. 